\title{
The Status of Waldo Frank in American Letters
}

By

Helge Normann Nilsen

University of Trondheim

Waldo Frank is a neglected figure in American literary and intellectual history. His name is perhaps not wholly unknown among students and scholars, but his works are out of print and very little has been published about him. He may be known to those who are interested in American poetry, because he edited and has written the foreword to the Complete Poems of Hart Crane (1933). Students of Afro-American fiction may also have come across his foreword to Jean Toomer's Cane (1923).

In the Literary History of the United States the authors, referring briefly to City Block (1922), speak of "the massive social studies of Waldo Frank," a phrase which suggests a positive response to the novel. ${ }^{1}$ However, Frank is only given scant, if any, attention in most works of literary history or criticism. ${ }^{2}$ His books were well known in the 1920s and '30s but since then they have become largely forgotten. ${ }^{3}$ It is only within the Spanish-speaking world that one can speak of a continuing interest in Frank's work, although it has not been established whether Frank is as known and read in these countries today as he used to be. ${ }^{4}$

But there is probably still a certain interest in Frank's work in the United States, and a feeling, at least in some circles, that a vital aspect of his contribution has been underrated and unhappily neglected. It is therefore important to redirect the attention toward those parts of Frank's work which remain significant. One essential aspect is his mystic and metaphysical approach to American culture in its most important manifestations, such as history, literature, art, politics, and religion.

Throughout his long career and in most of what he has written, Waldo Frank was inspired by an image of America as a new and 
promising world, and he was strongly motivated by a need to explore, define and promote what he regarded as the national identity and the central tradition of American cultural life. The titles of some of his works of cultural philosophy and criticism clearly indicate the nature of his central concern: Our America (1919), America Hispana (1931), The Re-Discovery of America (1929), and In the American Jungle 1925-1936 (1937).

Frank wanted to continue and renew the Whitman tradition in American life and letters, and he developed an organic philosophy similar to that of Whitman and applied it to American history and the American experience. Whether one agrees with this philosophy or not, it seems clear that it was essential for Frank himself and gave his cultural analyses as well as his creative work a background of profound personal commitment. One can speak of a national faith or mystique in connection with Frank and some of his contemporaries, such as Hart Grane, Alfred Stieglitz, Paul Rosenfeld, and Gorham Munson. Frank himself regarded many other American writers as his confrères in this cause and spoke of Carl Sandburg, Robert Frost, Sherwood Anderson and Van Wyck Brooks as "prospective captains of an army that must take over the country."

This army may not have succeeded in taking over the country, but the "movement", the "new American renaissance," has left a legacy that is important enough. In the case of Waldo Frank, a revival of his best work is certainly due at this point, and such hopes were also expressed during the 1950s by John Willingham, who then wrote: "Whitman, Thoreau, Melville, Emily Dickinson, Poe, and even Hawthorne, misunderstood or ignored by their contemporaries, had to be exhumed by militant young scholars and critics of the first world war period; and now that a thorough, objective sifting of the literary activity of the 1920's seems to be underway, doubtless Mr. Frank and his work are due for a considerable revival of interest."' One can only regret that these hopes have not been fulfilled in the years since this was written but it may also be that a thorough and balanced evalution of Franks' work as a whole must first be performed to give claims for a revival greater weight.

On the other hand, there are also reasons for his neglect. His work is uneven and has obvious weaknesses. It also has a core of strength and originality which needs further definition and illumination. As a literary artist, Frank is not without skill, but his novels are highly unconventional in the area of characterization and narrative technique. As often as not, the people in his novels are abstractions, 
the style is sometimes ponderous and occasionally impenetrable, and there is a general lack of story-telling effectiveness. The native mysticism that constitutes the core of Frank's vision is sometimes presented in a solemn and perhaps unconsciously naive fashion which may weaken its impact and make it seem opaque instead of profound. ${ }^{7}$ Humor and self-irony are also largely absent in Frank's fiction.

But Frank's early books about American culture and history, such as Our America (1919) and The Re-Discovery of America (1929), are sustained by a sweeping historical vision and also contains an accurate and still relevant analysis of the main characteristics of American civilization, its mores and preoccupations. It is mainly in the fiction that Frank's philosophical and analytic approach sometimes interferes with the literary artist's need to create fully fleshed characters and an intimate sense of human reality. But the mystic vision of America as a new "Whole" that is Frank's central concern is memorably expressed not only in the cultural studies, but also in certain passages in the novels. The boldness of Frank's metaphysical ambition in a novel like City Block, for example, is suggested by the epigraph from Spinoza: "By reality and perfection I understand the same thing." In the chapter called "Hope," the elevated train observed by the narrator becomes a symbol of the unity of all things, ${ }^{8}$ and in another novel from this period, Rahab, the heroine, Fanny Luve, has a similar experience or vision of God as an omnipresent, pantheistic principle.

The mystical experience that Frank sought to express reveals the unity and ultimate meaningfulness of the whole of life and reality, and does so in terms that are general enough to serve as a synthesizing and inclusive vision. Christian, Jewish and transcendentalist elements are combined, as it were, to form a religious response that will suit the needs of the emerging American nation that Frank described in the cultural histories. It was his hope that this response might become widespread and bring about a mental revolution that would transform American art, culture and life. This would be the proper use of the people's resources: "For that energy, to whatever form the mind consign it, is religious. Its act is creation. And in a dying world, creation is revolution."9 America, says Frank, is potentially an organic whole, divinely fashioned, and this can be revealed in the new art and culture. America also has a mystic tradition, going back to Columbus and the Puritans and blossoming in the work of Whitman. In the twentieth century, this tradition 
must not be abandoned, or else America will remain chaotic and fragmented. Frank exhorts his audience to take up this challenge and be guided by the light of this native tradition:

I write these words for those who will look on the possible American doom with a light heart: and not swerve from their task of self-creation and of leadership... they will not let their hands cease from the labor of beauty ... Having found wholeness in themselves ... They will act each hour to make themselves more true and to bring truth to bear upon the unborn world: not for any issue in time or person, but for the joy of the eternity of the moment lived in the image of God. The life of such men will be fulfillment of America's oldest tradition. And it may be that in their fulfillment a world called America will be discovered.10

Waldo Frank wrote several other novels and social studies than the ones referred to here, but his philosophy of national idealism and mysticism was fully and clearly outlined in the publications of the first 25 years of his career as a writer. His achievement as a philosopher of American culture in general and of the literature and art of the period between the two wars is substantial. His keen observations concerning the American writers of his own generation are informed both by his overall vision of American culture and his ability to perceive the individual characteristics of each. He understood better than anyone else what Hart Crane wanted to do in his cultural synthesis of America, The Bridge, and he perceived the fascination that native themes and concerns held for such writers as Sherwood Anderson, Robert Frost, Carl Sandburg and even Sinclair Lewis.

In his discussions of American literature and art lies one of Frank's principal contributions. His critical perspective is consistent and derives from a religious orientation that is radical and independent, just as it was in Whitman's work. Hence, Frank is able to illuminate an important tradition in American literature and grasp the essential message of poets like Crane, Sandburg or Frost: their willingness to rediscover, as it were, central human needs and experiences within their national materials. In his own creative work, Frank himself only sporadically succeeded in this endeavor, but there is no mistaking the nature of his theories and efforts. They succeeded the works of Whitman, Emerson and Thoreau and their "apocalyptic method," as Frank called it. ${ }^{11}$

What Frank sought and called for in American art and culture is both very simple and very radical. It is an attitude of mind that is open, pliable and ready to experience spiritual revelations. The artist will be able to experience directly the divine in the materials 
surrounding him and in the depths of his own being. Frank approached American literature and art in the light of this central focus and evaluated the various individuals and their work according to the degree to which they could be said to be struggling toward such an authentic, national and religious expression. It should be made clear at this point that Frank was anything but dogmatic in spiritual matters, and that he emphasized the importance of understanding the aspects of development and process within the work of the artist or writer. The struggle toward articulation, understanding or vision is part of the work itself, and that is the part which Frank seems most interested in. It is in accordance with his view of American culture as a process, promise or potential for new artistic and even social structures that will point toward the divine design of reality and prepare the way for the creation of new, whole and integrated persons. As always with Frank, it is the individual person who is the main focus of his philosophy and his hopes, as well as his fiction.

It seems reasonable to suppose that the majority of those who are interested in American literature can agree that Frank's status in American letters is a matter that needs further clarification and assessment before one can say that he has been given his proper place in American literary history. His importance may have been overestimated immediately after World War I, when Our America was hailed as "the Manifesto of the Twenties" and Gorham Munson called him "the most exciting figure in contemporary letters." 12 It is, however, also evident that the nearly total neglect of his work since then is not commensurate with his real achievement. What is needed is a basically sympathetic yet critical evaluation of Frank's writings, his influence on other writers and artists during the first decades of this century, and his place and significance in relation to them. ${ }^{13}$ Without a recognition of his achievement, the records of American literary and cultural history of the first half of the 20th century will remain incomplete.

\section{NOTES}

1 Spiller, et. al., Literary History of the United States, 3rd ed. (London, 1963), p. 1235.

2 Paul Carter has pointed out the reference to City Block in Literary History and quotes a few other statements about Frank in various works of literary history. See Waldo Frank (New York, 1967), pp. 182-183n, 185-186. Frederick J. Hoffman sees Frank, Sherwood Anderson and F. Scott Fitzgerald as three 
outstanding representatives of Freud's influence on American literature during the period between the wars. See Freudianism and the Literary Mind, 2nd ed. (Ann Arbor, 1967), pp. 250-263. Daniel Aaron discusses Frank's political activities and his involvement with left-wing causes in Writers on the Left (New York, 1961), pp. 209-210, 301-304 and 389-390.

3 See, for example, Carter, p. 172, William Bittner, The Novels of Waldo Frank (Philadelphia, 1955), pp. 15-16, and Lewis Mumford, Introd., The Memoirs of Waldo Frank, ed. Alan Trachtenberg (The University of Massachusetts Press, 1973), pp. xv-xvi.

4 See Carter, p. 97, 176. Spiller, et. al. inform that in 1941, a number of Spanish-language publishers listed "seven translations from Waldo Frank, more than from any other living North American writer." Literary History, p. 1387.

5 The Memoirs of Waldo Frank, p. 99.

6 Willingham, "The Achievement of Waldo Frank, The Literary Review, 1 (1958), 465.

7 For more detailed criticism, see, for example, Bittner's discussions of The Dark Mother and The Death and Birth of David Markand. The Novels of Waldo Frank, pp. 44-45, 147-148.

8 See City Block (New York, 1922), pp. 170-171. Robert L. Perry has suggested that this passage may have inspired Hart Crane to create his symbol of the Brooklyn Bridge. See The Shared Vision of Waldo Frank and Hart Crane (Lincoln, 1966), p. 35.

9 Our America (New York, 1919), p. 232.

10 The Re-Discovery of America: An Introduction to a Philosophy of American Life (New York, 1929), p. 310.

11 Ibid., p. 140.

12 Quoted in Carter, p. 172.

13 Severely critical responses to Frank's work were made early by Paul Rosenfeld (1921), and, a decade later, by Sidney Hook (1930). See Carter, pp. 173-174, 183.

Introductory paper read at a special session on the work of Waldo Frank at the Annual Convention of the Modern Language Association of America, New York, December 1978 